\title{
Teller's operculum; revising a rare operculate gastropod from the Silurian of Wisconsin (Laurentia)
}

\author{
John S. Peel
}

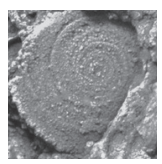

\begin{abstract}
The unique Silurian gastropod with the operculum in place which Edgar E. Teller in 1910 assigned to Murchisonia conradi Hall is redescribed. The date of authorship of Murchisonia conradi Hall, now transferred to Lophospira Whitfield, and originally described from the Racine Formation of Wisconsin (Laurentia), is established as 1865 and not 1867,1868 or 1870 as variously claimed. With a focus on the operculum, previous studies of Teller's specimen have neglected the form of the shell itself. Latex casts drawn from the external mould motivate its description as a new species, Lophospira telleri sp. nov., and demonstrate that the operculum was positioned deep within the shell aperture. Although being the only proven lophospiroidean operculum, the paucispiral sinistral (in external view) operculum is typical for dextral gastropods of moderate height in which the parietal wall is well developed and the umbilicus narrow. The development of opercula of this type, and the depth of emplacement of the operculum in L. telleri, may reflect increasing predation pressure on gastropods in the Lower Palaeozoic. Suggestions that the operculum of L. telleri may represent the inner surface of an operculum similar to that in the common Silurian euomphaloidean Oriostoma are rejected. In addition to the original record from Wisconsin, isolated opercula of L. telleri are now reported from Thornton Quarry, Illinois. - Key words: Silurian, operculate gastropod, Lophospiroidea, Laurentia.
\end{abstract}

Peel, J.S. 2018. Teller's operculum; revising a rare operculate gastropod from the Silurian of Wisconsin (Laurentia). Bulletin of Geosciences 93(4), 499-511 (4 figures). Czech Geological Survey, Prague. ISSN 1214-1119. Manuscript received September 23, 2018; accepted in revised form November 12, 2018; published online November 29, 2018; issued December 20; 2018.

John S. Peel, Department of Earth Sciences (Palaeobiology), Uppsala University, Villavägen 16, SE-75236 Uppsala, Sweden; john.peel@pal.uu.se

The helically coiled calcareous shell is the most familiar component of Palaeozoic fossil gastropods but the associated plate-like operculum, which closes the shell aperture as part of a defensive strategy against the unwanted attention of predators or environmental stress, is known in only a few taxa (Fig. 1). Then, as now, most opercula were likely organic in composition and unsuited to fossilisation, although fossil calcified opercula are known from strata as old as Early Ordovician and may be locally abundant (Yochelson 1979). Specimens preserved with the operculum in place are rare and, consequently, many of the few known examples are described (Lindström 1884; Perner 1903; Teller 1910; Knight 1941; Yochelson 1966, 1990; Yochelson \& Linsley 1972; Yochelson \& Wise 1972; Rohr \& Boucot 1984; Gubanov \& Yochelson 1994; Horný \& Peel 1995; Peel \& Horný 1996; Rohr \& Yochelson 1999; Rohr \& Frýda 2001; Rohr et al. 2004; Peel 2015). Most records are derived from Ordovician occurrences within the macluritoids and raphistomatid euomphaloids (Fig. 1). Apart from their interest as palaeontological curiosa, the operculated specimens provide added insight into gastropod evolution, mode of life, and anti-predation adaptation through almost half a billion years of earth history.
Teller (1910) described an enigmatic operculated specimen which occurred as an external mould from the Niagaran (Silurian) carbonates of Racine, Wisconsin, assigning the specimen to Murchisonia conradi Hall, also originally described from these strata. The paper by Teller (1910) settled the interpretation of some previously known spiral fossils from these strata as gastropod opercula rather than as gastropods themselves. Two such isolated opercula were also figured by Teller (1910). In Teller's (1910, pl. 150, fig. 1) publication, the operculate specimen is illustrated to present the in-place operculum to best effect. The gastropod shell is represented by a cavity (external mould) in the entombing dolomite and details of its morphology are poorly displayed.

Murchisonia conradi Hall is one of many gastropods described from the Silurian carbonate successions of the Great Lakes region (Laurentia) during the $19^{\text {th }}$ Century (Hall 1852, 1868, 1870, 1871; Winchell \& Marcy 1865; Hall \& Whitfield 1875; Whiteaves 1884). As with many of the others, Murchisonia conradi has remained largely undescribed since that time but this anonymity was broken when Teller (1910) described his operculate specimen from Racine. The latter has attracted passing comment 


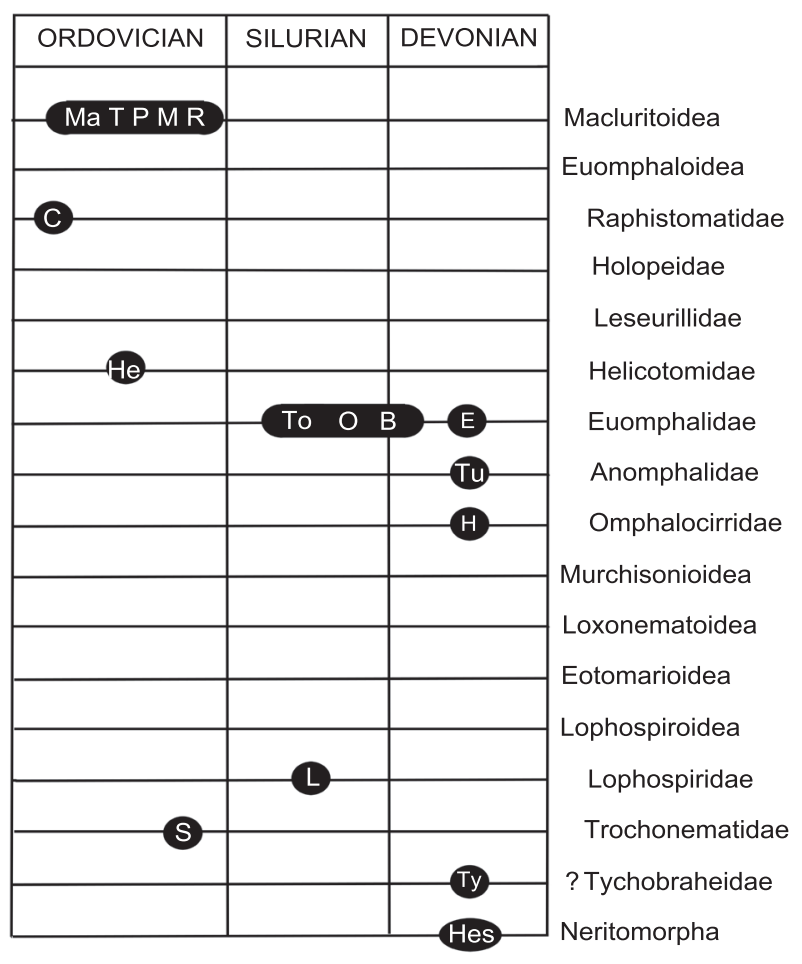

Figure 1. Stratigraphic distribution of Ordovician-Devonian gastropod opercula. Abbreviations: B - Beraunia Knight, 1937; C - Ceratopea Ulrich, 1911; E - Euomphalus northi Etheridge, 1890; H - Hypomphalocirrus Linsley, 1978; He - Helicotoma planulatoides Ulrich in Ulrich \& Scofield, 1897; Hes - Hessonia Bandel \& Heidelberger, 2001; L - Lophospira telleri sp. nov. (Murchisonia conradi of Teller 1910) and paucispiral operculum of Whiteaves (1891); Ma - Maclurites Le Sueur, 1818; M - Monitorella Rohr, 1994; O - Oriostoma MunierChalmas, 1876; P - Palliseria Wilson, 1924; R - Rousseauspira Rohr \& Potter, 1987; S - Slehoferia Rohr \& Frýda, 2001; T - Teichispira Yochelson \& Jones, 1968; To - Tophicola linsleyi Horný \& Peel, 1995; $\mathrm{Tu}$ - Turbinilopsis anacarina Tyler, 1965; Ty - Tychobrahea aerumnans Horný, 1992.

on account of the operculum (Yochelson \& Linsley 1972, Gubanov \& Yochelson 1994, Peel \& Horný 1996) but the gastropod shell itself has not been redescribed.

In this paper, Teller's (1910) operculated specimen is evaluated on the basis of latex casts drawn from the original external mould. The redescription involves comparison with descriptions of the holotype of Murchisonia conradi, although this was first accomplished after a review of the convoluted nomenclative history of that species. Surprisingly, the two specimens prove to be distinct and Teller's (1910) specimen is described therefore as a new species, Lophospira telleri sp. nov.

\section{Date of authorship of Murchisonia conradi Hall}

James Hall (1811-1898) was the most prolific American palaeontologist of his generation, and second only to
Joachim Barrande (1719-1883) on the international scene, but unravelling his bibliography is a challenge (Horowitz et al. 2017). Not surprisingly, a measure of confusion surrounds the date of the initial publication of Murchisonia conradi, largely as a result of the State Legislature of Wisconsin having decided to cut off funding for the Second Geological Survey of Wisconsin (1859-1863) in midterm (Allen \& Martin 1922). A paper by James Hall entitled 'Account of some new or little known species of fossils from rocks of the age of the Niagara Group' appeared in the $20^{\text {th }}$ Annual Report in which Hall (1868, p. 352) stated that the first part of the paper was originally printed in advance for inclusion in the $18^{\text {th }}$ Annual Report of the State Cabinet (Albany, New York).

The $20^{\text {th }}$ Annual Report is dated 1867 on its front cover, and this date is given by Miller (1877, p. 152), although Bassler (1915) and Horowitz et al. (2017, p. 77) gave the date of publication as 1868. In the original example available to me, this later date is documented by a loose printed slip of paper inserted into the Revised Edition of the $20^{\text {th }}$ Annual Report, stating that this revision was published in 1870 (Hall 1870) and not 1868, as printed on the cover, the latter being the date of publication of the First Edition. Hall (1868) is employed herein.

The initial printing of Hall (1868) took place during December 1864 and January 1865, as indicated by the printer's notations, and consists of 48 pages bearing page numbers $305-352$ of the $20^{\text {th }}$ Annual Report at the page head, but also page numbers $1-48$ at the page foot. Printing of the systematic descriptions continued from pages 353-381 at a later date (unspecified). Pages

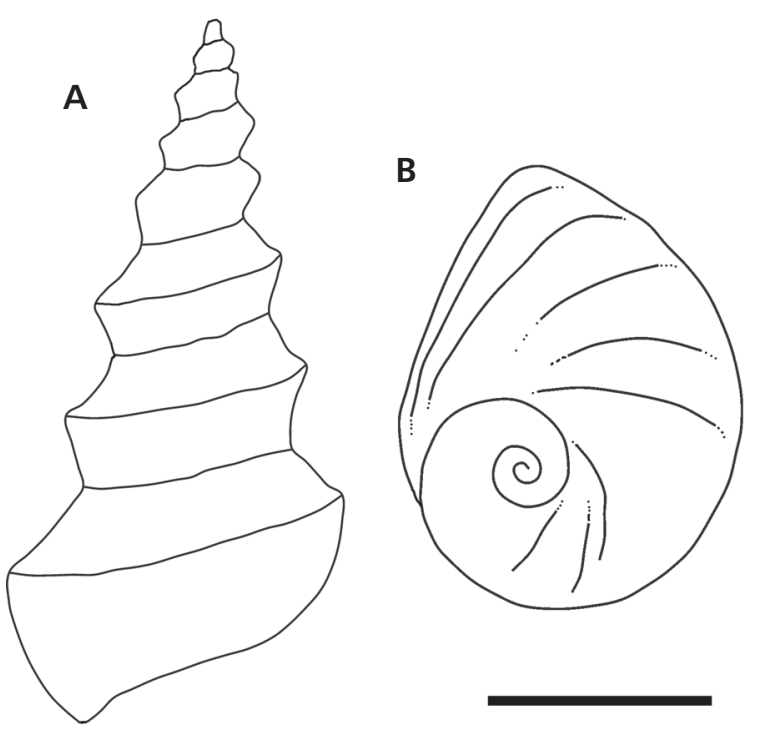

Figure 2. A - sketch of Murchisonia conradi Hall, 1865a showing the slender spire; drawn from Hall (1868); B - sketch of a paucispiral operculum from the Guelph Formation of Ontario, drawn from Whiteaves (1891). Scale bar is $15 \mathrm{~mm}$ for A and $10 \mathrm{~mm}$ for B. 
$305-351$ (1-47) carry the running head of ' $18^{\text {th }}$ Annual Report on the State Cabinet' whereas page 354 and later pages carry the running head ' $20^{\text {th }}$ Annual Report on the State Cabinet'.

The description of Murchisonia conradi as a new species occurs on pages 344-345 (alternatively pages 40-41) and includes no illustration or reference to an illustration, although Murchisonia conradi is illustrated as Hall [1868, pl. 15(6), fig. 19; its outline is sketched here as Fig. 2A], the plate labelled 'State Mus. Nat. Hist.' The accompanying caption identifies the illustration as Murchisonia conradi and states that the illustrated specimen (a guttapercha cast) is described on page 344 (40).

As noted above, a revised edition of the $20^{\text {th }}$ Annual Report was published in 1870 and not 1868 as printed on its cover (Hall 1870). Although some details of titles vary from the earlier version (Hall 1868), much of the text is largely unchanged; pagination is $347-438$, including an index, and the running head reads 'Report of the State Cabinet.' Murchisonia conradi is described as a new species on page 396 ; the description is identical to that of Hall (1868) except that a reference to plate 15, fig. 19 has been included. This plate is identical in terms of fossil illustrations to that in Hall (1868) except for the change in numbering style from Arabic to Roman. The plate caption states Murchisonia conradi, Hall, and refers to page 396.

In 1871 Hall issued a paper entitled 'Organic remains of the Niagara Group and associated limestones' in which the text is numbered pages 1-94; this pagination corresponds to pages $347-438$ of Hall (1870). Murchisonia conradi is described on page 52 , with reference to plate 25 , fig. 19. The plate is identical to Hall (1870, pl. 15), including the reference to 'State Mus. Nat. Hist. 20' (i.e. $20^{\text {th }}$ Annual Report), except in its renumbering as plate 25 .

James Hall was in the habit of distributing copies of his papers prior to their formal publication. Thus, the principal element of uncertainty concerning the date of first description of Murchisonia conradi results from the distribution in 1865 of copies of the text from his later paper (Hall 1868), as noted on page 353 (alternative 48) of the latter publication. This distribution is documented in a review in the American Journal of Science and Arts published in May 1865 (Anonymous 1865) of a paper by Hall printed in advance of publication (cited herein as Hall 1865a). Accompanying documentation clearly establishes that this is the same basic document scheduled for the illfated $18^{\text {th }}$ Annual Report of 1867 and the first few pages are reproduced verbatim in the review (Anonymous 1865). A detailed discussion of Hall's paper was given by Winchell \& Marcy (1865, p. 107), which paper was dated December 1865, although Murchisonia conradi was not mentioned.

Horowitz et al. $(2017$, p. 69 , items 464,465$)$ attributed this initial document to Hall, published on $26^{\text {th }}$ December
1864, but the last few pages were printed first in January 1865 (Hall 1865a, printer's notation on foot of page 41). Ironically, the first few lines of the description of Murchisonia conradi were printed in December 1864 (a date for publication of M. conradi cited by Whiteaves 1906, p. 331), and the bulk of the description first in January 1865 , as indicated by the printer's notations on the respective sections. The date of printing, of course, is not the same as the date of publication and neither of those dates has any proven validity from that point of view. According to Horowitz et al. (2017), item 465 was accompanied by plates [including plate 15(6) with Murchisonia conradi] whereas item 464 was not. The review in American Journal of Science and Arts, Second Series (Anonymous 1865) does not mention plates and is interpreted herein as Hall (1865a), referred to as Horowitz et al. (2017, item 464, but not published in 1864). Hall (1868, p. 352) commented that illustrations were added to the 1865 text at a later date, but the date of this comment which postdates the text and which has different typography than previous pages is not stated. Thus, the circulated version of the 1865 text with plates is apparently of later date than Hall (1865a), but its date of circulation is uncertain. It is not 1864 , as stated by Horowitz et al. (2017, item 465) since it contains text first printed in January 1865; it is arbitrarily listed here as Hall (1865b).

Thus, the same descriptive text is presented in at least five different settings (Hall 1865a, 1865b, 1868, $1870,1871)$. While no descriptions of fossils are given in the review extract in the American Journal of Science and Arts (Anonymous 1865), it is evident from this, and the comments of Winchell \& Marcy (1865), that Hall's (1865a) paper had been brought to the attention of a wide audience by being distributed as a preprint, and that this audience was greatly increased by the reviews in American Journal of Science and Arts and by Winchell $\&$ Marcy (1865). Application of the International Code of Zoological Nomenclature (1999) paragraph 21.8.1 indicates that the distribution of Hall (1865a) advanced the date of publication from the intended publication in the $18^{\text {th }}$ Annual Report (Hall 1868). Since the descriptive text accompanying the proposed new species Murchisonia conradi is deemed sufficient for diagnosis of the species, the date of authorship of Murchisonia conradi is attributed to Hall (1865a). The same date of authorship seemingly applies to other 'new' taxa described by Hall (1868, pp. 309-351). Descriptions of many of these taxa are repeated as new in Hall (1870), often with identical descriptions, but the page layout has changed relative to Hall (1868) and other taxa have been added or removed.

Despite the confusion surrounding date of publication, Murchisonia conradi was described on the basis of just a single external mould from the Silurian (Niagaran) of Racine, Wisconsin. Teller (1910, p. 1288) noted that this 
specimen was deposited in the American Museum of Natural History, New York, and a single specimen with this name is listed in the online database of that institution (specimen AMNH-FI 2095). Chamberlin (1883, p. 193) reproduced Hall's illustration of Murchisonia conradi without comment (Fig. 2A).

Whiteaves (1884, p. 27, pl. 4, fig. 6) described three well preserved specimens from the Guelph Formation at Elora, Canada, which 'should probably be regarded as a mere local variety' of Murchisonia conradi. He considered that they were not as slender as the type specimen from Wisconsin and their whorls were less carinate. Comparison of the illustrations suggests that these differences are trivial, although prominent comarginal rugose growth lines on the upper whorl surface of the holotype from Racine are not seen in Whiteaves' (1884) illustration. The assignment of the Elora specimens to Murchisonia conradi Hall, 1867 was restated by Whiteaves $(1895$, p. 80$)$.

Teller (1910, p. 1287, pl. 150) illustrated the operculate specimen of Murchisonia conradi which is the main subject of this paper (Fig. 3A-D). As with the holotype, it was also collected at Racine, Wisconsin. Both specimens are preserved as external moulds in dolomite but Teller's (1910) specimen is illustrated as such, while Hall's (1868, $1870,1871)$ specimen was figured as a cast made from the mould (Fig. 2A). The difference in presentation effectively precludes detailed comparison, not least since Teller's (1910) figure is focused on the operculum.

Whiteaves (1906, p. 331) transferred the Elora specimens of 'Murchisonia Conradi Hall, 1864' noted in Whiteaves $(1884,1895)$ to Lophospira conradi (Hall) without comment, but the 1864 date refers to the printer's notation of the date of printing rather than the date of distribution (see above). This assignment was restated by Bassler (1915, p. 759), although with Murchisonia conradi Hall, 1868 as the first citation.

Wing (1925, tab. 1) listed Lophospira conradi from the Niagaran of Thornton, north-eastern Illinois. The paper is the published summary of an unpublished Ph.D. dissertation (University of Chicago) in which Wing (1923, pp. 35, 36, pl. 2, fig. 8) described Lophospira conradi from Thornton Quarry, Thornton, Cook County, Illinois. However, the illustrated internal mould is quite clearly not attributable to Lophospira conradi (Hall, 1865a). Forney \& Nitecki (1976, p. 95) mentioned 3 specimens (one missing), cited by Wing (1925), from Thornton Quarry in the collection of the Field Museum, Chicago.

Yochelson \& Linsley (1972, p. 7) noted that Teller (1910) incorrectly assigned his specimen to Murchisonia conradi, although it is evident that their comment refers to the generic assignment rather than to Hall's species, and considered it to be a pleurotomarioidean. Comments concerning the operculum of Lophospira conradi (as
Murchisonia conradi), but not the taxonomic assignment, were made Gubanov \& Yochelson (1994, p. 490) and Peel \& Horný (1996, pp. 714, 715).

Summary. - Murchisonia conradi was validly proposed by Hall (1865a). The holotype and only known specimen is deposited in the American Museum of Natural History under specimen number AMNH-FI 2095. Murchisonia conradi was transferred to Lophospira conradi by Whiteaves (1906) and this placement is maintained herein.

Institutional abbreviations. - American Museum of Natural History, New York (AMNH); palaeontological type collection of the Museum of Evolution, Uppsala University, Sweden (PMU); U.S. National Museum of Natural History, Washington D.C. (USNM).

\section{Systematic palaeontology}

Suborder Murchisoniina Cox \& Knight, 1960

Superfamily Lophospiroidea Wenz, 1938

Family Lophospiridae Wenz, 1938

Discussion. - Classification of gastropods is currently in a state of flux, with many Lower Palaeozoic families reviewed in detail, but uncertainly placed, in the most modern syntheses (Bouchet et al. 2005, 2017). Lophospiridae Wenz, 1938 is one of the most conspicuous families in the Lower Palaeozoic and was placed by Knight et al. (1960) within the Superfamily Pleurotomarioidea Swainson, 1840, the latter grouped together with the Superfamily Trochonematoidea Zittel, 1895 and several other superfamilies within a Suborder Pleurotomariina Cox \& Knight, 1960. Wagner (2002) did not employ Pleurotomariina but recognised a Superfamily Lophospiroidea, which contained the Family Trochonematidae, within a Suborder Murchisoniina Cox \& Knight, 1960. Bouchet et al. (2017, p. 334) placed Lophospiridae within Trochonematoidea, which they considered as equivalent to the Lophospiroidea of Wagner (2002), assigning pleurotomarioids and murchisonioids as superfamilies to the vetigastropod Order Pleurotomariida. Trochonematoidea, however, was excluded from Pleurotomariida by Bouchet et al. (2017, p. 334), leaving its higher classification unresolved. Lophospiroidea is maintained herein as a superfamily within Murchisoniina to contain the nominate family, but the status of Trochonematidae is left in abeyance.

Lophospira telleri preserves the only Lower Palaeozoic operculum described from the Lophospiridae, although isolated opercula described by Whiteaves (1891) may be lophospirids. Slehoferia was placed within 


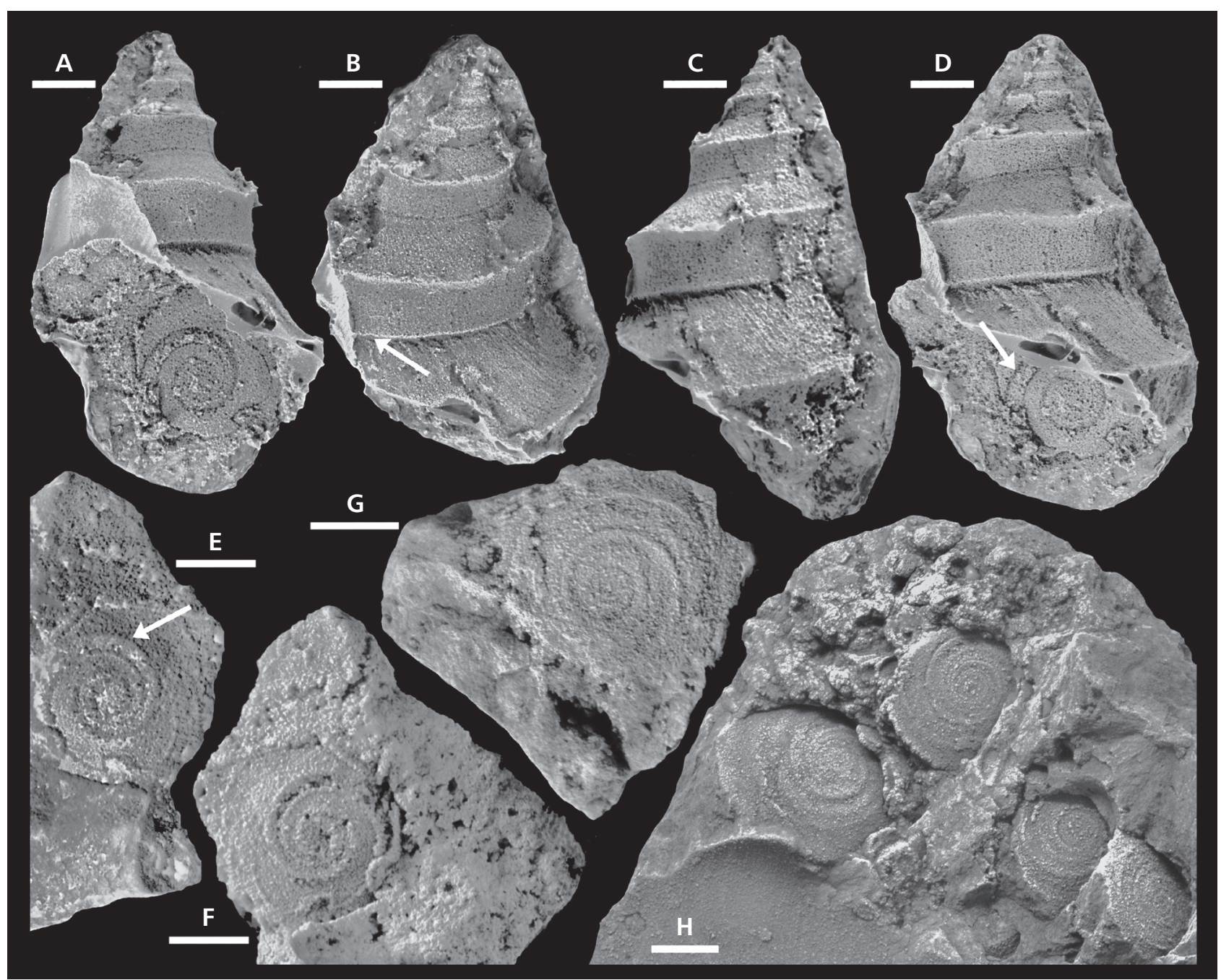

Figure 3. Lophospira telleri sp. nov., Racine Formation, Niagaran, Silurian, from Racine, Wisconsin, USA. • A-D - USNM 96660, holotype, latex impressions cast from the external mould; A - oblique apertural view showing the operculum in place; B - oblique lateral view showing ornamentation and spiral cord (arrow) developed at junction between outer whorl surface and basal surface; C - lateral view; D - lateral view showing the operculum positioned within the broken margin of the aperture, and a deep spiral groove (arrow) on the outer surface of the operculum. • E, F - USNM 314027a, operculum showing convex mould of external surface $(\mathrm{F})$ and digitally prepared cast $(\mathrm{E})$ representing the external surface of the operculum; arrow indicates spiral groove on outer surface of operculum. • G - USNM 314027b, convex mould of external surface of operculum. • H - PMU 33877, dental cement replica of small slab with external moulds of external surface of four opercula. Scale bars $=5 \mathrm{~mm}$.

Trochonematidae by Rohr \& Frýda (2001) but within the Superfamily Trochoidea Rafinesque, 1815 and not Lophospiroidea as suggested by Wagner (2002), the latter also followed by Ebbestad et al. (2008).

\section{Genus Lophospira Whitfield, 1886}

Type species. - Murchisonia bicincta Hall, 1847 from the Ordovician of New York (see discussion concerning naming of the type species by Knight 1941, p. 179).

\section{Lophospira telleri sp. nov.}

Figure 3
1910 Murchisonia conradi Hall. - Teller, pp. 1287, 1288, pl. 150 , figs $1-3$.

Holotype. - USNM 96660 from the Niagaran (Silurian) of Racine, Wisconsin. External mould of shell and operculum.

Type horizon and locality. - Carbonate mounds of the Racine Formation, Niagaran Series, Silurian; Racine, Wisconsin.

Material. - Illustrated material: USNM 314027a, b, two of three opercula from Racine preserved under that collection number (a fourth specimen is not an operculum). 
Specimen number USNM 314027a (=Fig. 3G) was illustrated by Teller (1910, pl. 150, fig. 2) but the identity of Teller (1910, pl. 150, fig. 3) as one of the other two specimens preserved under USNM 314027 is not demonstrated. Specimen number PMU 33877, a dental cement replica which I made in 1970 of an un-numbered specimen from Racine, Wisconsin, in the Teller Collection, U.S. National Museum of Natural History (Fig. 3H). Four opercula are preserved on the small slab of dolomite that also contains external moulds of gastropods and a cephalopod. The original specimen has not been located in currently inaccessible collections. The specimen was illustrated by Peel (1987, fig. 14.30c).

Additional material: USNM 314027c, an operculum from Racine, Wisconsin. Specimen number PMU 33875 and 33876, two opercula which I collected from Thornton Quarry, Illinois, in summer 1970.

Etymology. - For Edgar Eugene Teller (1845-1923) of Buffalo, New York. Edgar Teller worked in the meat packaging industry all his life, but was an avid collector and accomplished amateur palaeontologist (Teller 1924).

Diagnosis. - Shallowly sinuate, slender, species of Lophospira with an incremental angle of about 53 degrees, flattened upper whorl surface without spiral carina; peripheral carina lacking a selenizone. Prominent spiral carina at junction between outer whorl surface and base.

Description. - Turreted, with six or more whorls and an incremental angle of about 53 degrees. The whorl profile of the whorl surface exposed in the spire is divided at mid height by a peripheral carina. The upper whorl surface is flat, inclined from the slightly adpressed suture towards the peripheral carina. The outer whorl surface is shallowly concave between the peripheral carina (above) and a prominent spiral cord (below) at the junction with the base (Fig. 3B, arrow). The outer lip is prosocline on the upper whorl surface, as indicated by straight growth lines that slope backwards at an angle of about 55 degrees from the suture with the previous whorl before increasing slightly in adapical curvature immediately prior to joining the peripheral carina. Growth lines on the outer whorl surface are almost orthocline but show slight adapical curvature just below the peripheral carina, indicating a shallow peripheral sinus. The peripheral carina is the locus of a narrow, shallow, notch but a selenizone is not generated. The basal surface is not well known, but seemingly uniformly convex. The nature of the narrow umbilicus is not known. Ornamentation consists solely of fine growth lines which become slightly irregular on the upper whorl surface at the latest preserved growth stage.
The operculum is sub-circular, slightly tear-shaped and paucispiral; its concave external surface shows four or more whorls which carry a prominent spiral groove (Fig. 3A, E arrows). The inner surface of the operculum is poorly known, but it was shallowly convex and possibly smooth. The operculum was capable of withdrawal into the shell by up to one quarter of a shell whorl.

Discussion. - The holotype of Lophospira telleri has an estimated total height of about $38 \mathrm{~mm}$, about $10 \mathrm{~mm}$ less than the holotype of $L$. conradi. It has a much greater incremental angle (about 53 degrees) than the holotype of Lophospira conradi (about 34 degrees; Fig. 2A) and lacks the gently prosocline, rugose comarginal growth lines seen on the upper whorl surface of the latter. Additionally, a prominent spiral cord at just above the following suture in Lophospira telleri (Fig. 3B, arrow) is not present in L. conradi. The spiral cord delimits the shallowly concave outer whorl face from the base, whereas the entire whorl surface below the angular periphery is convex in L. conradi. In terms of incremental angle and the uniformly convex base, Whiteaves' (1884) specimen from the Guelph Formation is closely comparable to the type of $L$. conradi.

Lophospira telleri resembles Lophospira sedgwicki Longstaff, 1906 from the lower Silurian of Scotland and Arisaig, Nova Scotia (Peel 1977) in lacking prominent spiral carinae on the upper whorl surface. In Lophospira sedgwicki, however, the incremental angle is about 33 degrees, compared with 53 degrees in the holotype of L. telleri. Furthermore, the prominent peripheral carina formed at the junction of the upper and outer whorl surfaces lies below mid height of the exposed whorl surface in L. sedgwicki, but at mid height in L. telleri.

\section{Operculum of Lophospira telleri}

It is a character of gastropod opercula that the operculum, when viewed externally and in place within the gastropod shell aperture, coils in the opposite direction to the direction of coiling of the shell (Peel \& Horný 1996, text-fig. 1; Checa \& Jiménez-Jiménez 1998). Thus, in a normally coiled dextral (clockwise) gastropod, the operculum appears to be coiled anticlockwise (sinistral) when viewed from the exterior (Fig. 4A). It may be difficult, however, to discern the direction of coiling if the operculum is coiled through multiple slowly expanding whorls, as is the case in the familiar Siluro-Devonian gastropod Oriostoma Munier-Chalmas, 1876 (Lindström 1884, Peel 2015).

A sinistrally coiled operculum appears to be coiled dextrally when viewed from its inner surface (Fig. 4C). Likewise, moulds of the external and internal surfaces of the operculum appear to have the opposite direction of 

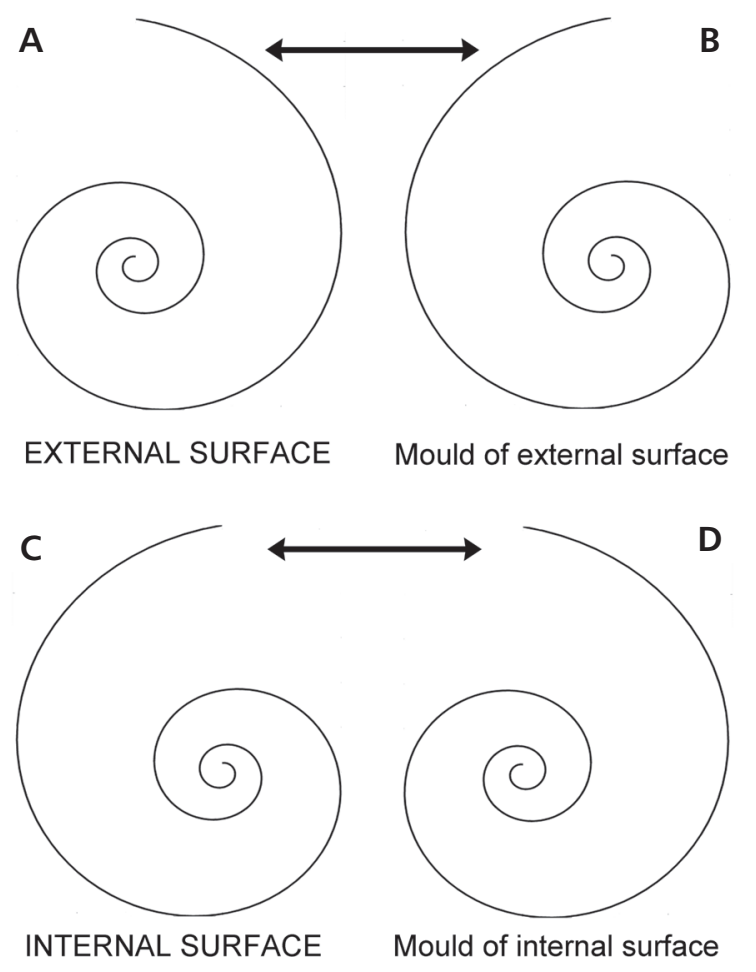

Figure 4. Views of a sinistrally coiled paucispiral operculum; A - view of external surface, sinistral coiling; B - mould of external surface, dextral coiling; $\mathrm{C}$ - view of internal surface, dextral coiling; D - mould of internal surface, sinistral coiling.

coiling to the corresponding operculum surfaces themselves (compare Fig. 4A and B, 4C and D). It is potentially confusing that a mould of the internal surface is coiled in the same fashion as the operculum itself in external view (compare Fig. 4A and D). In most gastropods, however, the inner and outer surfaces of the operculum are dissimilar.

The operculum in the illustration of Lophospira telleri given by Teller (1910, pl. 150, fig. 1) is coiled dextrally and his comment that it is the convex mould of the operculum exterior is correct. A similar convex external mould (Fig. 3F) has been digitally manipulated to restore the original concave external surface of the operculum (Fig. 3E), and the latter is directly comparable to the operculum in place within the aperture (Fig. 3A, D).

The three isolated opercula of Lophospira telleri in USNM 314027 have a diameter of about $12 \mathrm{~mm}$ and are preserved as shallowly convex moulds of a concave surface (Fig. 3F, G). The moulds are coiled dextrally (clockwise) indicating that coiling of the opposing original surfaces of the opercula were sinistrally (anticlockwise) coiled (Fig. 3E). Yochelson \& Linsley (1972) apparently supported this interpretation in commenting that the outer surface of the operculum itself was concave. Gubanov \& Yochelson (1994, p. 490), however, commented that the operculum illustrated by Teller (1910) was coiled in the 'wrong' direction, interpreted here to mean that it was coiled dextrally (as in Teller's illustration) when it should have been coiled sinistrally in a dextral shell. They overlooked the fact this is a mould of the external surface of the operculum and, as such, it is coiled correctly. Instead, they explained their suggested anomaly by claiming that the operculum as illustrated was the imprint of the internal surface of an operculum of Oriostoma type, as illustrated by Rohr \& Boucot (1984). Oriostoma is unusual in that its external surface is multispirally coiled in sinistral fashion whereas its internal surface may be paucispirally coiled in its most central part, but also sinistrally coiled, as evident from illustrations by Lindström (1884, pl. 17) and Rohr \& Boucot (1984). The coiling on the concave inner surface of specimens illustrated as Lindström (1884, pl. 17, figs 53 and 55) is sinistral in its central portions but this paucispiral pattern ceases abruptly, passing into very closely spaced multispiral whorls as the periphery of the operculum is approached. The direction of coiling of the multispiral outer zone can not be ascertained due to the fineness of the individual revolutions. As noted by Rohr $\&$ Boucot (1984), it is clearly anomalous that the exterior and interior operculum surfaces are both sinistrally coiled (compare Fig. 4A and C). However, an additional specimen illustrated by Lindström (1884, pl. 17, fig. 18) preserves fine, strongly prosocline radial striations in the inner, paucispirally coiled, portion of the inner surface that demonstrate a muscle migration scar. This appears to confirm the suggestion of Linsley in Rohr \& Boucot (1984), with which I concur, that the structure of the inner surface may be an artifact of muscle migration. Thus, deposition of calcareous material occurred on the internal surface of the operculum as distinct from just on the outer surface, a process not known in present day gastropods (Checa \& Jiménez-Jiménez 1998). Additionally, the operculum of Oriostoma was situated at the apertural margin (Lindström 1884, Peel 2015) whereas the operculum in Lophospira telleri was located deep within the shell.

Whatever the structure of the problematic Oriostoma operculum, it is evident that Teller's operculum is not of Oriostoma type. The preserved surface is not a mould of the internal surface, as suggested by Gubanov \& Yochelson (1994), but a mould of the external surface (compare with Fig. 4B), as suggested by Teller (1910), Yochelson \& Linsley (1972) and Peel \& Horný (1996). This is also evident from the overall configuration of the specimen, as preserved. All original calcium carbonate traces of the holotype of Lophospira telleri (shell, operculum, diagenetically calcite-filled interior plug) have been dissolved, leaving a cavity in the entombing dolomite. A plug of this dolomitised matrix extends for a quarter of a whorl into the aperture of the shell, terminating at the exterior surface of the in place operculum and preserving a mould of its exterior surface. Similar preservation was 
described by Rohr \& Frýda (2001) in their new genus Slehoferia.

A number of moulds of the external surface are available in isolated opercula from Racine (Fig. $3 \mathrm{~F}-\mathrm{H}$ ) and two additional specimens are now known from Thornton, Illinois. The moulds are typically shallowly convex and dextrally coiled, indicating that the corresponding outer surface of the original operculum was concave and sinistral (compare Figs $3 \mathrm{E}$ and F, 4A and B). No moulds of the interior surface have been recognised, but cavities around the periphery of the dolomite internal moulds (Fig. 3H), resulting from dissolution of the calcite opercula, strongly suggest that the internal surface was shallowly convex and smooth. It is not unlikely that such small smooth objects were overlooked by collectors in the coarsely preserved dolomite while the prominent spiral pattern on the outer surface more readily caught the eye.

Whiteaves (1891) described isolated paucispiral opercula (Fig. 2B) from the Guelph Formation of Durham, Ontario, which attained a maximum length of $20 \mathrm{~mm}$, some 60 percent larger than the operculum of Lophospira telleri. Yochelson \& Linsley (1972, p. 7) suggested that Whiteaves' (1891) specimen was probably the same as Teller's (1910) example, but it lacks the prominent spiral groove of the latter (Fig. 3D, E, arrows). Both have a concave outer surface but this displays fewer and more rapidly expanding whorls in the Guelph specimen than in Lophospira telleri. The internal surface of both specimens is unknown. Whiteaves (1891) recognised that the operculum was unlike previously described Palaeozoic opercula and suggested possible association with Holopea gracia Billings, 1865 or Holopea harmonia Billings, 1865 (Discordichilus harmonia Billings, 1865 of Wagner 2017). However, the discordance in probable orientation between the long axis of the operculum (Fig. 2B) and the aperture in these specimens makes such a restoration unlikely. Juxtaposition of the growing edge of the operculum against the parietal wall, with the orientation as illustrated by Whiteaves (1891, p. 406; Fig. 2B), suggests a taller shell, possibly one of several lophospirids recorded from the Guelph Formation by Whiteaves $(1884,1895,1906)$. The operculum of Tophicola linsleyi Horný \& Peel, 1995, from the late Silurian Kopanina Formation of the Czech Republic, differs from Whiteaves' (1891) specimen in having a greater number of whorls with a much lower rate of whorl expansion.

Peel \& Horný (1996) noted the similarity between the paucispiral opercula of Lophospira telleri (as Murchisonia conradi) and the holopeiform Tychobrahea aerumnans Horný, 1992 from the lower Devonian Dvorce-Prokop Limestone of the Czech Republic. They believed Tychobrahea to be hyperstrophically coiled on the basis of the supposed dextrally coiled external surface of the operculum which differs in direction of coiling to that of the sinistral operculum in Lophospira telleri. Thus, the convex external surface of the operculum in Tychobrahea aerumnans has similar relief and convexity to the mould of the exterior surface of Lophospira telleri (Fig. 3F, H). Unfortunately, the internal surface of the operculum in Tychobrahea aerumnans is unknown, as is also the case in Lophospira telleri.

Tophicola linsleyi from the late Silurian of the Czech Republic has a globose turbiniform shell with rounded whorls and deep sutures (Horný \& Peel 1995). The operculum is located at the apertural margin and not deeply withdrawn into the shell as in Lophospira telleri. The external surface of the paucispiral operculum is flat with a small concave central disc surrounded by numerous slowly expanding whorls. The outer surface of the whorls is shallowly convex without the spiral groove seen in L. telleri (Fig. 3D, E, arrow); the inner surface is not well known but seems to show a similar coiling style to the exterior (Horný \& Peel 1995).

Cyclonema lilydalensis Etheridge, 1891 (transferred to Australonema by Tassell 1980) has a more rapidly expanding, turbiniform, shell than Lophospira telleri. A paucispiral operculum in place was described in a single specimen by Yochelson \& Linsley (1972), although a second specimen was noted by Tassell (1980). Unlike Lophospira telleri, the operculum is located at the apertural margin and not deeply withdrawn into the shell. The operculum of Australonema lilydalensis has distinctly different outer and inner surfaces. The outer surface is shallowly convex, paucispiral, with only shallow grooves separating the slowly expanding whorls. Six or more slowly expanding whorls are present, clearly more than in Lophospira telleri, the latter differing also in its concave outer surface with a prominent groove on the last whorl. The inner surface of the operculum in A. lilydalensis shows fewer, wider whorls and its coiling spiral is much closer to that of the outer surface of L. telleri. However, each whorl overhangs the previous whorl to form deep sutures and a deepened central area. Thus, in its overall morphology, the outer surface of the operculum in A. lilydalensis resembles the upper surface of a sinistral lenticular gastropod, with a smooth spire and shallow sutures, whereas the inner surface resembles the umbilical surface, with deep umbilical sutures and a deep, open, umbilicus. Australonema varvarae Gubanov \& Yochelson, 1994 from the Silurian of north-western Siberia, south of Norilsk, differs from A. lilydalensis in having the prominent spiral ornamentation consisting of acute ridges separated by wider concave channels, whereas the specimen illustrated by Yochelson \& Linsley (1972) has broader convex ridges separated by narrower grooves. Although in place, the operculum is not well preserved, but it was located at the aperture, rather than withdrawn; it is seemingly paucispiral but with more 
whorls than Lophospira telleri, although Gubanov \& Yochelson (1994, fig. 3) considered the possibility of it being multispiral.

Helicotoma planulatoides Ulrich in Ulrich \& Scofield, 1897, from the Ordovician Tyrone Limestone of Kentucky is a low spired, widely phaneromphalous gastropod with a circular aperture (Yochelson 1966). Two co-occurring, but isolated, opercula are paucispiral with three or four whorls and a convex, slightly stepped whorl surface, interpreted by Yochelson (1966) as the sinistrally coiled outer surface. The opposing surface has a depressed centre but is less easily interpreted; one illustrated specimen appears to be spirally coiled but with fewer whorls than the outer surface, probably indicating deposition on the interior of the operculum in similar fashion to Oriostoma (Yochelson 1966, text-fig. 1b). Following treatment and examination of the silicified samples, Yochelson (1966) was confident in assigning the isolated specimens to Helicotoma planulatoides, which is the most common gastropod in the sample from Kentucky, although shells of Lophospira and Trochonema also occur in the sample. However, the paucispiral coiling is unusual for low-spired gastropods, where the operculum in such genera as Euomphalus ('Liomphalus') northi Etheridge, 1890, Ceratopea Ulrich, 1911, Maclurites Le Sueur, 1818, Monitorella Rohr, 1994, Oriostoma, Turbinilopsis anacarina Tyler, 1965, Slehoferia Rohr \& Frýda, 2001 is multispiral or multispiral concentric. The supposed opercula of Helicotoma planulatoides compares more closely with those of the higher spired Australonema, Tychobrahea, Tophicola and Lophospira, and it remains a possibility that these isolated opercula were associated with a higher spired shell rather than the low spired Helicotoma planulatoides.

Slehoferia, from the Zahořany Formation (Ordovician) of Bohemia was assigned to Trochonematidae by Rohr \& Frýda (2001), but as a trochoidean rather than a lophospiroidean. The operculum in the tiny, low spired gastropod is circular and its multispiral form reflects the weakly developed parietal wall within the circular aperture. In this respect it is unlike Lophospira telleri where the operculum is paucispiral and the parietal wall well developed, although opercula in both species have a concave external surface and are deeply withdrawn.

\section{Opercular form and evolution}

The opercula of present day pleurotomarioids are not calcified (Checa \& Jimenéz-Jimenéz 1998, Harasewych 2002). Classified as flexicaudent multispiral by Checa $\&$ Jimenéz-Jimenéz (1998), the pleurotomarioid operculum grew when it was extended beyond the shell aperture. On withdrawal, the flexible multispiral organic plate was drawn deeply in, with its margins bent against the shell wall. Similar opercula are present in many trochids (Hickman $\&$ McLean 1990). Due to the flexibility, significant calcification can not occur in this type of operculum. In contrast, the calcified operculum of Lophospira telleri would be classified as rigicaudent paucispiral by Checa \& Jimenéz-Jimenéz (1998). Accretion occurred when the inflexible operculum was withdrawn into the shell, using the inner shell wall as a template, although the concave shape of the outer surface may suggest that the extreme margin of the operculum was slightly flexible and might have been bent to form a tighter seal. Paucispiral rigicaudent opercula are developed in turbinids and the inner surface shows a degree of coiling similar to that seen on the outer surface of the operculum of Lophospira telleri. However, the outer surface of turbinid opercula is massively calcified, the familiar 'cat's eyes' of tropical beaches (Vermeij \& Williams 2007).

Checa \& Jiménez-Jiménez (1998) noted that the consistent distribution of flexicaudent or rigicaudent opercula in higher gastropod taxa at the present day indicated their utility in evolutionary systematics. Most rigicaudent opercula are paucispiral, but multispiral rigicaudent opercula, although less frequent, are widely distributed. Thus, the distinction between paucispiral and multispiral is less useful in systematics than that between flexicaudent or rigicaudent, as is also the case with spiral versus concentric coiling (Checa \& Jiménez-Jiménez 1998).

In the evolutionary model proposed by Checa \& Jiménez-Jiménez (1998), loosely coiled, multispiral, flexicaudent operculum gave rise to multispiral rigiclaudent and then paucispiral rigiclaudent opercula. Concentrically coiled rigiclaudent opercula were considered to have been derived from paucispiral rigiclaudent opercula, which show a close match between the operculum margin and shell, by lengthening of the zone of deposition. Checa \& Jiménez-Jiménez (1998) concluded, however, that the fossil record of opercula does not provide reliable evidence for the evolution of opercular types which is perhaps as expected considering the paucity of fossil specimens (Fig. 1). Such evidence as is available from the Palaeozoic suggests that multispiral (and or concentric) rigiclaudent opercula appear before paucispiral rigiclaudent forms (Fig. 1). However, preservation of flexicaudent opercula can not be expected on account of their lack of calcification. Furthermore, gastropods such as Oriostoma, Turbinilopsis and Helicotoma added calcareous material to the operculum interior whereas calcification only occurs on the outer surface of present day gastropods. Most of the Ordovician forms, such as the mainly Early Ordovician Ceratopea and Teichispira, and the slightly younger Maclurites and Palliseria, had rigiclaudent but generally concentric opercula. Many of these opercula show an element of spiral coiling but this seems often to 
reflect accommodation of the helical coiling of the shell rather than spiral growth of the operculum itself.

As noted above, the oldest known clearly spiral, paucispiral, opercula from the Middle Ordovician, referred by Yochelson (1966) to Helicotoma planulatoides, appear to be anomalous as regards the association of a rigiclaudent paucispiral operculum with a low spired shell with a circular aperture. Yochelson \& Linsley (1972) suggested that this may represent convergence in the paucispiral opercular form between the low spired Helicotoma and the moderately high spired Lophospira telleri (as Murchisonia conradi) and Australonema (as Cyclonema lilydalensis), to which may be added Tophicola. Alternatively, correlation of rigiclaudent paucispiral opercula with the higher spired shell of the three turbiniform gastropods, and likely also with the opercula described by Whiteaves (1891), provides evidence that the association of the isolated paucispiral opercula with Helicotoma planulatoides, although logically proposed by Yochelson (1966), may require re-examination. In this context, it is also relevant to note that Lindström $(1884$, pl. 17, figs 53, 55) illustrated a clearly defined paucispiral sinistral coiling pattern on the internal surface of some oriostomatid opercula from the Silurian of Gotland, Sweden, which, in terms of the rate of expansion of the spiral, is similar to that seen on the surface described as exterior by Yochelson (1966, text-fig. 1a) in Helicotoma planulatoides. A circular aperture is characteristic of Oriostoma and several species illustrated by Lindström (1884) have low spired shells similar to Helicotoma planulatoides.

The association of pronounced calcification and the concentric or rigiclaudent multispiral form of opercula with the low spired shell form of many Lower Palaeozoic gastropods reflects an antipredatory response on account of their sedentary mode of life. This is the most common association of operculated gastropods in the Ordovician and also finds a parallel within the oriostomatids and omphalocirrids of the Silurian-Devonian. In terms of the pronounced calcification, parallels can be drawn with the present day turbinids which lack escape strategies against slow predators and consequently develop massively calcified opercula (Vermeij \& Williams 2007).

The appearance of several genera with a paucispiral operculum in the Silurian-Devonian may reflect an increase in predation pressure upon gastropods whose motility had previously served as their main defensive strategy. Again, present day turbinids provide a viable model (Vermeij \& Williams 2007). This interpretation as a response to increasing predation pressure gains further support from the deep placement of the operculum in Lophospira telleri when compared to most of the other forms since an operculum located at the apertural margin is more easily removed during durophagous or other predatory attacks (Peel 2015). It is also possible, however, that the deep placement is a synapomorphy of the presumed flexicaudent condition in the earliest gastropods, the late Cambrian to Early Ordovician sinuopeids of Wagner (2002). Their opercula may have been multispiral, as in recent pleurotomarioids and trochids, but the turbinate shell form, with a tear-shaped aperture and well developed parietal wall, suggests that their opercula may have been paucispiral. As evident from present day pleurotomariids, with a deep sinus and slit in the outer lip (Harasewych 2002), flexicaudent opercula can be withdrawn deep into the shell interior, providing superior protection against peeling back of the apertural margin by predators.

As regards the oldest known fossil gastropod opercula, Checa \& Jiménez-Jiménez (1998) speculated as to whether or not macluritids were ancestral to the mainly older Ceratopea, or vice versa, in terms of the nature of the coiling of their opercula. However, the difference in shell form and mode of life reflected in their taxonomic separation (Knight et al. 1960, Wagner 2002) suggests that they may represent unrelated calcification events, without a shared evolutionary relationship, in the sporadic geological record of operculated gastropods.

\section{Conclusions}

The date of first publication of the Laurentian Silurian gastropod Murchisonia conradi Hall is established as 1865 (Hall 1865a); it is currently assigned to Lophospira.

The operculate gastropod from the Racine Formation (Silurian) of Wisconsin which Teller (1910) assigned to Murchisonia conradi is re-described as Lophospira telleri sp. nov. The unique specimen preserves a mould of the outer surface of the shell and the calcified operculum, with the operculum preserved in place and deeply withdrawn into the aperture. The specimen represents the only known unequivocal association of a lophospiroidean gastropod and operculum from the Palaeozoic.

The paucispiral form of the rigiclaudent operculum reflects the presence of a well developed parietal wall within the gastropod aperture, a feature of moderately high spired gastropod shells with a high degree of impression of the previous whorl. Although rare, the several records of this type of operculum from the Silurian suggest that increasing predation pressure may have stimulated the development of a calcified operculum in moderately high spired gastropods which had previously relied upon their mobility to escape from predators.

\section{Acknowledgements}

Jann Thompson and Doug Erwin (U.S. National Museum of Natural History, Washington D.C.) facilitated the loan 
of specimens from Racine. Bushari M. Hussaini (American Museum of Natural History, New York) and Mark Florence (U.S. National Museum of Natural History) provided information concerning specimens in their care. Christian B. Skovsted (Naturhistoriska Riksmuseet, Stockholm) arranged access to collections from Gotland, Sweden. Reviews by Jan Ove R. Ebbestad (Museum of Evolution, Uppsala) and David M. Rohr (Sul Ross State University, Alpine, Texas) are gratefully acknowledged.

\section{References}

Allen, R.C. \& Martin, H.M. 1922. A brief history of the geological and biological survey of Michigan: 1837 to 1872 , by R.C. Allen; 1872 to 1920, by Helen M. Martin. Michigan History Magazine 6(No. 44), 1-23.

Anonymous, 1865. Account of some new or little known species of fossils from rocks of the age of the Niagara Group, by Prof. James Hall. American Journal of Science and Arts, Second Series 1865 39, 353-355.

Bandel, K. \& Heidelberger, D. 2001. The new family Nerrhenidae (Neritimorpha, Gastropoda) from the Givetian of Germany. Neues Jahrbuch für Geologie und Paläontologie Monatshefte 12, 705-718.

BASSLER, R.S. 1915. Bibliographic index of American Ordovician and Silurian fossils. United States National Museum, Bulletin 92, 1-1521.

Billings, E. 1865. Palaeozoic fossils, volume 1. 426 pp. Geological Survey of Canada. Dawson Brothers, Montreal \& Quebec.

Bouchet, P., Rocroi, J.F., Frýda, J., Hausdorf, B., Ponder, W., VALDÉs, Á. \& WARÉN, A. 2005. Classification and nomenclator of gastropod families. Malacologia 47, 1-397.

Bouchet, P., Rocroi, J.P., Hausdorf, B., Kaim, A., Kano, Y., Nützel, A., Parkhaev, P., Schrödl, M. \& Strong, E.E. 2017. Revised classification, nomenclator and typification of gastropod and monoplacophoran families. Malacologia 61, 1-526. DOI 10.4002/040.061.0201

Chamberlin, T.C. 1883. Geology of Wisconsin, Volume. 1. 784 pp. Commissioners of Public Printing, Madison, Wisconsin.

ChecA, A.G. \& Jimenéz-Jimenéz, A.P. 1998. Constructional morphology, origin, and evolution of the gastropod operculum. Paleobiology 24, 109-132.

DOI 10.1017/S0094837300020005

Cox, L.R. \& Knight, J.B. 1960. Suborders of the Archaeogastropoda. Proceedings of the Malacological Society of London 33, 262-264.

Ebbestad, J.O.R., Bassett, M.G., Dastanpour, M. \& Popov, L.E. 2008. Ordovician (Caradoc) Gastropoda of the Katkoyeh Formation, Kerman Province, Iran. Geobios 41, 605-624. DOI 10.1016/j.geobios.2008.01.004

Etheridge, R. JR 1890. Descriptions of Upper Silurian fossils from the Lilydale Limestone, Upper Yarra district, Victoria. Records of the Australian Museum 1, 60-67.

DOI 10.3853/j.0067-1975.1.1890.1227

Etheridge, R. JR 1891. Further descriptions of the Upper Silurian fossils from the Lilydale Limestone, Upper Yarra District, Victoria. Records of the Australian Museum 1, 125-130. DOI 10.3853/j.0067-1975.1.1891.1244

Forney, G.G. \& Nitecki, M.H. 1976. Type fossil Mollusca (Hyolitha, Polyplacophora, Scaphopoda, Monoplacophora, and Gastropoda) in Field Museum. Fieldiana Geology 36, 1-240.

Gubanov, A.P. \& Yochelson, E.L. 1994. A Wenlockian (Silurian) gastropod shell and operculum from Siberia. Journal of Paleontology 68, 486-491.

DOI 10.1017/S0022336000025877

Hall, J. 1847. Palceontology of New - York. Volume I. Containing descriptions of the organic remains of the lower Division of the New-York System. 333 pp. C. Van Benthuysen, Albany.

Hall, J. 1852. Palceontology of New - York. Volume II. Containing descriptions of the organic remains of the lower Middle Division of the New - York System. 362 pp. C. Van Benthuysen, Albany.

Hall, J. 1865a. Account of some new or little known species of fossil from rocks of the age of the Niagara Group. Printed in advance, for the $18^{\text {th }}$ Report of the New-York State Cabinet, 1-48. Albany.

Hall, J. 1865b. XIX. Account of some new or little known species of fossils from rocks of the age of the Niagara Group. Printed in advance for the $18^{\text {th }}$ Report on the New-York State Cabinet, 305-401. Albany.

Hall, J. [1867] 1868. XIX. Account of some new or little known species of fossils from rocks of the age of the Niagara Group. $20^{\text {th }}$ Annual Report of the Regents of the University of the State of New-York on the condition of the State Cabinet of Natural History, 305-401. Van Benthuysen \& Sons, Albany.

Hall, J. 1870. Descriptions of new or little-known species of fossils from rocks of the age of the Niagara Group. II. Descriptions of fossils of the Niagara Group. $20^{\text {th }}$ Annual Report of the Regents of the University of the State of New York, on the condition of the State Cabinet of Natural History. Revised Edition, 351-434. Van Benthuysen \& Sons, Albany.

Hall, J. 1871. Organic remains of the Niagara group and associated limestones, 3-94. In Geological Survey of the State of Wisconsin (1859-1963): Palceontology, Part Third. Albany.

Hall, J. \& Whitfield, R.P. 1875. Report of the Geological Survey of Ohio. Volume II. Geology \& Palaeontology. Part II. Palaeontology. 435 pp. Nevins \& Myers, Columbus, Ohio.

Harasewych, M.G. 2002. Pleurotomarioidean gastropods. Advances in Marine Biology 42, 237-294.

DOI 10.1016/S0065-2881(02)42015-9

Hickman. C.S. \& McLean, J.H. 1990. Systematic revision and suprageneric classification of trochacean gastropods. Natural History Museum of Los Angeles County, Scientific Series 35, $1-169$.

HornÝ, R.J. 1992. New Lower Devonian Gastropoda and Tergomya (Mollusca) of Bohemia. Časopis Národniho Muzea, Řada prírodovédná 159, 99-119.

Horný, R.J. \& PeEL, J.S. 1995. A new Silurian gastropod from 
Bohemia with the operculum in situ. Journal of the Czech Geological Society 40, 79-88.

Horowitz, A.S., Nitecki, M.H. \& Nitecki, D.V. (edited by Ausich, W.I.) 2017. Bibliography of James Hall (1811-1898). Bulletins of American Paleontology 392, 1-146.

International Code of Zoological Nomenclature 1999 [2012]. Fourth edition with amendments 2012. International Commission on Zoological Nomenclature. http://www.iczn. org/iczn/index.jpp

Knight, J.B. 1937. Genotype designations and new names for invalid homonyms among Paleozoic gastropod genera. Journal of Paleontology 11, 709-714.

Knight, J.B. 1941. Paleozoic gastropod genotypes. Geological Society of America Special Papers 32, 1-510. DOI 10.1130/SPE32-p1

Knight, J.B., Batten, R.L. \& Yochelson, E.L. 1960. Paleozoic gastropods, 169-331. In Moore, R.C. (ed.) Treatise on invertebrate paleontology. University of Kansas Press, Lawrence.

Le Sueur, C.A. 1818. Observations on a new genus of fossil shells. Journal of the Academy of Natural Sciences of Philadelphia 1, 310-313.

Lindström, G. 1884. On the Silurian Gastropoda and Pteropoda of Gotland. Kungliga Svenska Vetenskaps Akademiens Handlingar 19, 1-250.

Linsley, R.M. 1978. The Omphalocirridae: a new family of Palaeozoic Gastropoda which exhibits sexual dimorphism. Memoirs of the National Museum of Victoria 39, 33-54. DOI 10.24199/j.mmv.1978.39.03

LongstafF, J. 1906. Notes on the genera Omospira, Lophospira, and Turritoma; with descriptions of new Proterozoic species. Quarterly Journal of the Geological Society of London 62, 552-572. DOI 10.1144/GSL.JGS.1906.062.01-04.28

Miller, S.A. 1877. The American Palaeozoic fossils: a catalogue of the genera and species. 293 pp. Published by the author, Cincinnati, Ohio.

Munier-Chalmas, E. 1876. Mollusques nouveaux des terrains paléozoïques des environs de Rennes. Journal de Conchyliologie, $3^{e}$ série 16, 102-109.

Peel, J.S. 1977. Systematics and palaeoecology of the Silurian gastropods of the Arisaig Group, Nova Scotia. Det Kongelige Danske Videnskabernes Selskab, Biologiske Skrifter 21(2), $1-89$.

Peel, J.S. 1987. Class Gastropoda, 305-328. In Boardman, R.S., Cheetham, A.H. \& Rowell, A.J. (eds) Fossil invertebrates. Blackwell Scientific Publications, Palo Alto.

PeEL, J.S. 2015. Operculum regeneration and failed predation in the Silurian gastropod Oriostoma. Palaeontology 58, 229-237. DOI 10.1111/pala.12154

Peel, J.S. \& Horný, R.J. 1996. Sinistral hyperstrophic coiling in a Devonian gastropod from Bohemia with an in situ operculum. Palaeontology 39, 709-718.

Perner, J. 1903. Systême Silurien du centre de la Bohême par Joachim Barrande. Vol. IV Gastéropodes 1, Texte (Patellidae et Bellerophontidae) et Planches 1 à 89.164 pp. Fr. Řivnáč, Prague.

RAFINESQue, C.S. 1815. Analyse de la nature ou tableau de l'univers et des corps organisés. 223 pp. Jean Barravecchia, Palerme.

RoHR, D.M. 1994. Ordovician (Whiterockian) gastropods of Nevada: Bellerophontoidea, Macluritoidea, and Euomphaloidea. Journal of Paleontology 68, 473-486. DOI 10.1017/S0022336000025865

RoHr, D.M. \& Boucot, A.J. 1984. Observations of the operculum of Oriostoma (Silurian Gastropoda). Canadian Journal of Earth Sciences 22, 294-296. DOI 10.1139/e85-026

RoHr, D.M. \& FrÝDA, J. 2001. A new Ordovician gastropod and operculum from the Czech Republic. Journal of Paleontology 75, 461-462. DOI 10.1017/S0022336000018242

Rohr, D.M. \& Potter, A.W. 1987. Rousseauspira: new gastropod operculum from the Ordovician of Akaska and California. Journal of Paleontology 61, 284-289.

DOI 10.1017/S0022336000028468

Rohr, D.M. \& Yochelson, E.L. 1999. Life association of shell and operculum of Middle Ordovician gastropod Maclurites. Journal of Paleontology 73, 1078-1080. DOI 10.1017/S0022336000030997

Rohr, D.M., Fix, M.F. \& Darrough, G. 2004. Life association of shell and operculum of Ceratopea Ulrich, 1911 (Ordovician; Gastropoda). Journal of Paleontology 78, 218-220. DOI 10.1666/0022-3360(2004)078<0218:LAOSAO >2.0.CO;2

SWAINSON, W. 1840. A treatise on malacology or shells and shellfish. 419 pp. Longman, London.

TAssell, C.B. 1980. Further gastropods from the early Devonian Lilydale Limestone, Victoria. Records of the Queen Victoria Museum 69, 3-27.

Teller, E.E. 1910. An operculated gastropod from the Niagara Formation of Wisconsin. Transactions of the Wisconsin Academy of Sciences, Arts, and Letters 16, 1286-1288.

Teller, E.E. (Mrs) 1924. Memorial of Edgar E. Teller, 182-184. In BAssler, R.S. (ed.) Proceedings of the fifteenth annual meeting of the Paleontological Society, held at Washington D.C., December 27-29, 1923. Bulletin of the Geological Society of America 35, 169-200.

TYLER, J.H. 1965. Gastropods from the Middle Devonian Four Mile Dam Limestone (Hamilton) of Michigan. Journal of Paleontology 39, 341-349.

Ulrich, E.O. 1911. Revision of the Paleozoic systems. Geological Society of America Bulletin 22, 281-680.

DOI 10.1130/GSAB-22-281

Ulrich. E.O. \& Scofield, W.H. 1897. The Lower Silurian Gastropoda of Minnesota. Geology of Minnesota Final Report 3(2), 813-1081.

Vermeij, G.J. \& Williams, S.T. 2007. Predation and the geography of opercular thickness in turbinid gastropods. Journal of Molluscan Studies 73, 67-73.

DOI 10.1093/mollus/eyl032

Wagner, P.J. 2002. Phylogenetic relationships of the earliest anisostrophically coiled gastropods. Smithsonian Contributions to Paleobiology 88, 1-152. DOI 10.5479/si.00810266.88.1

Wagner, P.J. 2017. Taxonomic occurrence of Discordichilus harmonia Billings 1865 recorded in the Paleobiology database, Fossilworks. http://fossilworks.org 
Wenz, W. 1938-44. Gastropoda. Teil 1: Allgemeiner Teil und Prosobranchia (Amphigastropoda $u$. Streptoneura). In ScHINDEWolf, O.H. (ed.) Handbuch der Paläozoologie 6. 1639 pp. Gebrüder Borntraeger, Berlin.

Whiteaves, J.F. 1884. On some new, imperfectly characterized or previously unrecorded species of fossils from the Guelph Formation of Ontario. Palaeozoic Fossils 3(1), 1-43. DOI $10.4095 / 131596$

WhiteaVes, J.F. 1891. Note on the occurrence of paucispiral opercula of Gasteropoda in the Guelph Formation of Ontario. The Canadian Record of Science 4, 404-407.

Whiteaves, J.F. 1895. Revision of the fauna of the Guelph formation of Ontario, with descriptions of a few new species. Palaeozoic Fossils 3(2), 45-109. DOI 10.4095/131597

Whiteaves, J.F. 1906. Revised list of the fossils of the Guelph formation of Ontario. Palaeozoic Fossils 3(4), 327-340. DOI $10.4095 / 131603$

WhitFIELD, R.P. 1886. Notice of geological investigations along the eastern shore of Lake Champlain, conducted by Prof. M. Seely and Prest. Ezra Brainerd, of Middlebury College, with descriptions of some new fossils discovered. Bulletin of the American Museum of Natural History 1, 293-345.

WiLSON, A.E. 1924. A new genus and a new species of gastropod from the Upper Ordovician of British Columbia. Canadian Natural History 1, 81-114.

Winchell, A. \& MARCy, O. 1865. Enumeration of fossils collected in the Niagara Limestone at Chicago, Illinois, with descriptions of several new species. Boston Society of Natural History, Memoir 1, 81-112.

WiNG, M.E. 1923. The Silurian Gastropoda of northeastern
Illinois. 111 pp. Ph.D. thesis, University of Chicago, Chicago, Illinois.

WING, M.E. 1925. The Silurian Gastropoda of northeastern Illinois. Abstracts of theses. University of Chicago Science Series 1, 311-317.

Yochelson, E.L. 1966. An operculum associated with the Ordovician gastropod Helicotoma. Journal of Paleontology 40, 748-749.

Yochelson, E.L. 1979. Gastropod opercula as objects for paleobiogeographic study, 37-43. In Gray, J. \& Boucot, A.J. (eds) Historical biogeography, plate tectonics, and the changing environment. Oregon State University Press, Corvallis, Oregon.

Yochelson, E.L. 1990. Billings' second operculum: a late Early Ordovician Maclurites (Gastropoda) from western Newfoundland and the Canadian Arctic. Canadian Journal of Earth Sciences 27, 669-676. DOI 10.1139/e90-064

Yochelson, E.L. \& Jones, C.R. 1968. Teichispira, a new Early Ordovician gastropod genus. U.S. Geological Survey Professional Paper 613-B, 1-15.

Yochelson, E.L. \& Linsley, R.M. 1972. Opercula of two gastropods from the Lilydale Limestone (Early Devonian) of Victoria, Australia. Memoirs of the National Museum of Victoria 33, 1-13. DOI 10.24199/j.mmv.1972.33.01

Yochelson, E.L. \& WISE, O.A. JR 1972. A life association of shell and operculum in the early Ordovician gastropod Ceratopea unguis. Journal of Paleontology 46, 681-684.

Zittel, K.A. von 1895. Grundzüge der Paläontologie (Paläozoologie), Abt. 1, Invertebrata. 971 pp. Oldenburg, Munich and Leipzig. 